\title{
EFEKTIFITAS PROBLEM POSING PADA LEARNING CYCLE 5E TERHADAP HASIL BELAJAR DAN BERFIKIR TINGKAT TINGGI PADA MATERI KELARUTAN DAN HASIL KALI KELARUTAN
}

\author{
I wayan Dasna, Suhadi Ibnu, Fajar Nugroho \\ Universitas Negeri Malang \\ E-mail: fajaraljabir@gmail.com
}

\begin{abstract}
Abstrak: Tujuan dari penelitian ini adalah untuk mengetahui efektifitas problem posing pada learning cycle $5 E$ dalam meningkatkan hasil belajar dan kemampuan berfikir tingkat tinggi. Problem posing diterapkan pada fase explanation dan fase elaboration. Rancangan penelitian menggunakan quasi experimental dengan posttest only non equivalent control group design. Data penelitian adalah hasil belajar dan kemampuan berfikir tingkat tinggi. Hasil penelitian menunjukkan bahwa 1) terdapat peningkatan hasil belajar siswa yang dibelajarkan dengan learning cycle 5E-problem posing dari pada kelas learning cycle $5 E$ ditinjau dari kemampuan awal siswa, 2) terdapat peningkatan kemampuan berfikir tingkat tinggi siswa yang dibelajarkan dengan learning cycle 5E-problem posing dari pada kelas learning cycle $5 E$ dari kemampuanawal siswa, 3)Tidak terdapat interaksi kemampuan awal dengan model pembelajaran terhadap hasil belajar dan kemampuan berfikir tingkat tinggi siswa.
\end{abstract}

Kata Kunci: problem posing,learning cycle $5 E$, hasil belajar, kemampuan berfikir tingkat tinggi

\section{PENDAHULUAN}

Kelarutan dan hasil kali kelarutan merupakan materi kimia kelas XI bidang Matematika dan Ilmu Alam (MIA) dalam Kurikulum 2013 tingkat Sekolah Menengah Atas (SMA) (Kemendikbud, 2014). Kelarutan dan hasil kali kelarutan termasuk materi yang sulit bagi siswa (Gilbert dan Treagust, 2009: 6; Kelly dkk, 2010; Barke dkk, 2009: 32; Brown dan Votaw, 2008; Tan dkk, 2009: 139), hal ini juga dibuktikan pada hasil Ujian Akhir Nasional (UAN) SMA tahun 2013 menunjukkan nilai rata-rata kimia masih minimum sebesar 64, 94, termasuk nilai kompetensi kelarutan dan hasil kali kelarutan sebesar 68, 04 (Balitbang, 2013). Johnston (2000) menyimpulkan permasalahan ilmu kimia dipandang sulit oleh siswa karena dua alasan yaitu karakteristik materi dan proses pembelajaran siswa. Alasan ini berkaitan erat dengan konten dan proses pembelajaran dalam memahami kelarutan dan hasil kali kelarutan. Pemahaman konten dan proses diperlukan sehingga masalah dapat teratasi.

Pemahaman konten berkaitan dengan karakteristik materi ilmu kimia. Johnston (2000) mengemukakan bahwa karakteristik khas ilmu kimia terdiri dari representasi makrokopis, submikrokopis, dan simbolik. Kesulitan siswa menghubungkan ketiga aspek representasi menjadikan ilmu kimia menjadi sulit (Gilbert dan Treagust, 2009: 6). Representasi submikrokopis yang bersifat abstrak dan kompleks menambah kesulitan bagi siswa seperti fenomena kelarutan garam dengan submikro berupa atom dan molekul yang diubah menjadi ion-ion sehingga membentuk endapan senyawa ionik, kemudian hal ini akan bertambah kompleks ketika ion poliatomik seperti fosfat dan nitrat (Berkel dkk, 2009: 32; Brown dan Votaw, 2008).

Kesulitan siswa dialami dalam mempelajari representasi submikrokopis dan simbolik itu sendiri (Wu dkk, 2001; Kelly dkk, 2010). Kelly dkk. (2010) mencotohkan siswa belum mengetahui alasan terjadi peristiwa pengendapan akibat tarikan elektostatis antar ion-ion. Tan dkk. (2009: 139-141) menjelaskan kelemahan siswa dalam memahami persamaan ionik menyebabkan siswa sulit memahami endapan dapat larut ketika 
ditambahkan pelarut, penambahan asam pada campuran alkali akan menambah kelarutan, dan memahami hasil endapan dari reaksi dekomposisi seperti siswa tidak dapat menjelaskan fenomena pembentukan endapan seng hidroksida $\left(\mathrm{Zn}(\mathrm{OH})_{2}\right)$ akibat penambahan larutan natrium hidroksida $(\mathrm{NaOH})$ ke dalam larutan seng $(\mathrm{Zn})$ dengan reaksi sebagai berikut:

$$
\mathrm{Zn}^{2+}(a q)+2 \mathrm{OH}^{-}(a q) \rightarrow \mathrm{Zn}(\mathrm{OH})_{2}(s)
$$

Barke (2009: 156-167) dan Krause dan Tasooji (2007) juga menambahkan siswa sering salah memahami hasil kali kelarutan bergantung pada jumlah padatan, dan siswa memahami hasil kali kelarutan garam tidak terbatas bukan menggunakan prinsip Le Chatelier. Raviolo (2001) menjelaskan representasi simbolik meliputi rumus, simbol kimia dan persamaan kimia memiliki kesulitan yang besar dibanding dengan repsesentasi makrokopis dan submikrokopis. Permasalahan yang menyangkut kuantitatif kimia, khususnya dalam reaksi kimia selalu menuntut penalaran yang proposional (Effendy, 1985: 51).

Konten materi kelarutan dan hasil kali sebagai bagian dari ilmu kimia secara umum yaitu materi luas dan abstrak, terdiri dari konsep-konsep yang berkelanjutan dan algoritmik (Effendy, 2002: 1). Kean dan Middlecamp (1985: 26-27) menambahkan bahwa materi kimia bersifat kompleks dimana setiap konsep saling berhubungan satu sama lain. Pemahaman siswa terhadap konten materi yang baik berkaitan ketiga representasi ilmu kimia akan memudahkan mereka dalam memahami kimia, khususnya materi kelarutan dan hasil kali kelarutan.

Proses pembelajaran siswa menjadi permasalahan pokok, setelah konten materi. Proses pembelajaran siswa jarang mengkaitkan representasi makrokopis, submikrokopis dan simbolik melalui penulisan persamaan ionik sehingga tidak bisa memahami proses pengendapan dan factor-faktor yang mempengaruhi kalarutan (Tan dkk, 2009: 139-141). Berkel dkk. (2009: 32) menambahkanprsoses pembelajaran jarang melibatkan berfikir representasi makrokospik sampai mikrokospik (micro-macro thinking), yaitu mengkaitkan fakta kelarutan dengan ion-ion yang menyusunnya. Pembelajaran kelarutan dan hasil kelarutan di Banyuwangi khususnya di SMAN 1 Glagah lebih cenderung guru menggunakan verifikasi konvensional dalam proses pembelajaran di kelas sehingga siswa belum mengoptimalkan kemampuan mereka. Rahayu (2013) menjelaskan pembelajaran yang kurang variatif dapat berakibat siswa pasif, kurang kompetitif dan interaktif.

Kontruksi pengetahuan menjadi kunci keberhasilan dalam pembelajaran. Menurut (Bodner, 1986) pembelajaran merupakan proses kognitif yang terjadi oleh kontruksi pengetahuan didalam diri siswa. Proses kognitif tersebut akan melahirkan perubahan konsep yang akan mempengaruhi hasil belajar (De Jong dkk, 2013). Perubahan konsep dari keadaan pemahaman disiquilibrium menjadi iquilibrium. Teori kontruktivisme memandang pengetahuan science tidak diberikan langsung dari siswa oleh guru, melainkan siswa aktif membangun pengetahuan sendiri 'learning science as an individual activity' (Driver dkk, 1944: 6). Proses pembelajaran yang menekankan siswa terlibat aktif sangat diperlukan dalam pembelajaran (student centered learning) (King dkk, 2011). Siswa yang terlibat aktif dalam pembelajaran akan lebih mengkontruksi pemahaman mereka dengan pengetahuan baru sehingga diharapkan dapat memaksimalkan hasil belajar mereka. Pentingnya keaktifan siswa dalam pembelajaran (student centered learning) merupakan hal yang ditekankan dalam implementasi kurikulum 2013 (Kemendikbud, 2014). 
Salah satu alternatif mengatasi permasalahan tersebut adalah menerapkan model pembelajaran learning cycle 5E-problem posing. Learning cycle 5E- problem posing merupakan model pembelajaran kontruktivisme hasil perpaduan learning cycle $5 E$ dan problem posing yang diharapkan dapat meningkatkan hasil belajar siswa dari pada verifikasi konvensional. Problem posing yaitu siswa membuat soal dilakukan pada fase explanation dan elaboration dalam learning cycle 5E. Siswa bukan hanya aktif menjelaskan solusi permasalahan yang diberikan guru fase explanation melainkan juga aktif memperkuat argumen mereka dengan soal yang telah dibuat. Siswa juga aktif mengerjakan dan membuat soal yang lebih kompleks pada fase elaboration.

Perpaduan learning cycle 5E-problem posing didasarkan beberapa alasan sehingga diharapkan bisa lebih efektif meningkatkan pemahaman siswa. Pertama, karakteristik sintaks yang lebih mendorong siswa terlibat aktif dalam mengontruksi pemahaman dalam pembelajaran (Abraham dan Renner, 1986; Duran dkk, 2011; Chua dan Yeap, 2009). Kedua, setiap fase learning cycle 5E dan soal yang dibuat dalam problem posing memberikan kesempatan guru mengukur pemahaman siswa sehingga dapat segera dievaluasi dan diperbaiki, misalnya learning cycle dapat mencegah adanya miskonsepsi (Guzetti dkk, 1993). Karplus (1997) mengemukakan kunci pemahaman siswa terletak pada respon siswa ketika menghadapi masalah, apakah mereka mampu atau tidak mampu. Ketiga, problem posing akan meningkatkan problem solving (English, 1997). Mengingat problem solving termasuk bagian dari fase elaboration (Dasna dan Fajaroh, 2007). Siswa membuat soal dan solusinya akan melatih siswa mengerjakan soal dengan baik. Keempat, materi kelarutan dan hasil kelarutan terdapat unsur konseptual dan algoritmik yang diharapkan melalui problem posing dapat menbantu learning cycle $5 E$ dalam meningkatkan pemahaman siswa lebih optimal. Problem posing memberikan kesempatan siswa untuk melakukan inkuiri dalam membuat soal sehingga menambah minat dan kepercayaan diri mereka (Chua dan Yeap, 2009).

Pemahaman ilmu kimia sangat dibutuhkan kemampuan berfikir tingkat tinggi dalam menjawab permasalahan yang lebih kompleks, misalnya menganalis adanya pengaruh jenis ion untuk mengedapkan kation-kation tertentu, mendesain percobaan pengendapan, dan lain-lain. Menurut Rahayu (2016) kemampuan berfikir tingkat tinggi dapat ditinjau dari berfikir kritis (Ennis), transfer kognitif (Bloom Taxonomy) yaitu C4 (menganalisa masalah), C5 (mengevaluasi masalah), C6 mendesain (mencipta) inkuiri ilmiah, dan problem solving. Learning cycle 5E-problem posing diharapkan dapat meningkatkan kemampuan berfikir tingkat tinggi siswa dengan mengacu bahwa sintaks pembelajaran yang memenuhi lima tahapan model peningkatan berfikir kritis oleh Duron (2006).

Kemampuan awal berkontribusi dalam meningkatkan pemahaman siswa dan kemampuan berfikir tingkat tinggi (Thompson dan Zamboanga, 2004). King dkk. (2011: 1) menambahkan kemampuan berfikir tingkat tinggi didasarkan kemampuan awal dalam berinteraksi dengan materi melalui strategi pembelajaran. Learning cycle 5E-problem posing terdapat tahap engaggemant dengan menggali kemampuan awal siswa sehingga diharapkan dapat meningkatkan hasil belajar dan kemampauan berfikir tingkat tinggi siswa. Kegiatan menggali kemampuan awal siswa oleh guru akan menambah daya tarik siswa untuk belajar (Svinicki, 1993-1994).

\begin{tabular}{lll}
\hline Fase & Learning cycle $5 E$ - problem possing & Learning cycle $5 \mathrm{E}$ \\
\hline
\end{tabular}




\begin{tabular}{lll}
\hline 1 & Engagement & Engagement \\
2 & Exploration & Exploration \\
3 & Explanation+ Problem posing & Explanation \\
4 & Elaboration+ Problem posing & Elaboration \\
5 & Evaluation & Evaluation \\
\hline
\end{tabular}

Tabel 1 Perbandingan Learning cycle $5 E$-problem possing dengan Learning cycle $5 E$

\section{METODE PENELITIAN}

Metode penelitian yang digunakan adalah penelitian eksperimen semu (quasi experimental) dengan rancangan posttest only non equivalent control group design. Penelitian dilakukan semester genap tahun ajaran 2015-2016 pada bulan April-Mei 2016. Penelitian bertempat di SMAN 1 Glagah, Banyuwangi. Penelitian dilaksanakan sepuluh kali pertemuan dengan rincian yaitu sembilan kali pertemuan untuk penerapan model pembelajaran dan satu kali pertemuan $(3 \times 45$ menit) untuk ujian akhir.Sampel penelitian 90 siswa terdiri 3 kelas XI MIA.

Instrumen penelitian yang digunakan dalam penelitian ini terdiri dari instrumen perlakuan dan pengukuran. Instrumen perlakuan yang digunakan adalah silabus, Rancangan Pelaksanaan Pembelajaran (RPP), Lembar Kerja Siswa (LKS) yang disesuaikan dengan model pembelajaran yang digunakan, bahan ajar, dan petunjuk praktikum. Instrumen pengukuran yang digunakan adalah tes hasil belajar berupa tes objektif 23 soal dan tes subjektif 7 soal termasuk 13 soal objektif dan7 soal subjektif untuk tes kemampuan berfikir tingkat tinggi.

Berdasarkan validasi oleh tiga ahli, diperoleh validitas silabus dan RPP sebesar $100 \%$, LKS dan petunjuk praktikum sebesar $98 \%$, dan bahan ajar sebesar 97,2\%, dan soal tes prestasi belajar sebesar $88,94 \%$. Setelah diuji coba siswa MIA SMAN 1 Giri, Banyuwangi memperoleh reliabilitas Cronbach 'sAlpha sebesar 0,970 sehingga instrumen tes reliabel. Analisis data yang digunakan adalah analisis deskriptif dan statistik inferensial. Analisis deskriptif dengan menjelaskan fenomena sampel di dalam penelitian yang dapat ditinjau dari proses belajar mengajar, penyelesaian lembar kerja siswa, dan penyelesaian alasan jawaban tes hasil belajar siswa. Analisis statistik inferensial dengan anakova untuk mengetahui pengaruh model pembelajaran ditinjau dari kemampuan awal siswa terhadap hasil belajar dan kemampuan berfikir tingkat tinggi.

\section{HASIL DAN PEMBAHASAN}

Data yang diperoleh dari penelitian ini meliputi: (1) hasil belajar dan kemampuan berfikir tingat tinggi siswa, (2) uji pengaruh learning cycle 5E-problem posing terhadap hasil belajar dan kemampuan berfikir tingat tinggi siswa , dan (3) keterlaksanaan tahapan learning cycle 5E-problem posing.

(a) Hasil belajar dan kemampuan berfikir tingkat tinggi siswa ditinjau dari kemampuan awal

Rata-rata hasil belajar siswa pada tes akhir terlihat pada Gambar 1. 


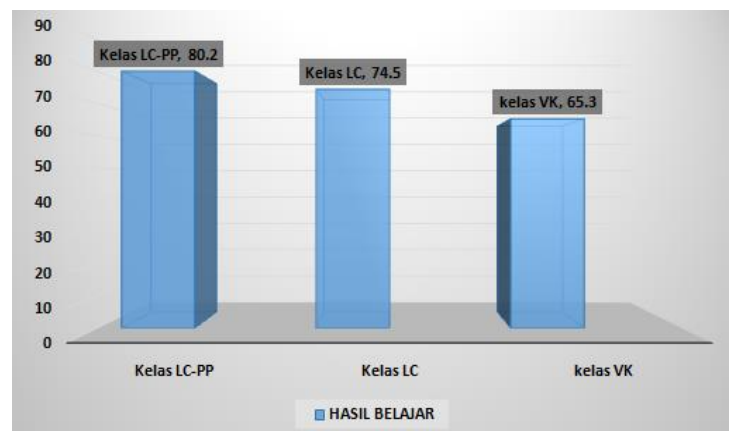

\section{Gambar 1 Hasil Belajar Siswa ditinjau dari Tes Akhir}

Berdasarkan Gambar 1 dapat diketahui bahwa siswa yang dibelajarkan learning cycle $5 E$ - problem posing mendapat rata-rata hasil belajar $(80,2)$ yang lebih baik dari pada kelas learning cycle $5 E(74,5)$ dan kelas verifikasi konvensional $(65,3)$.

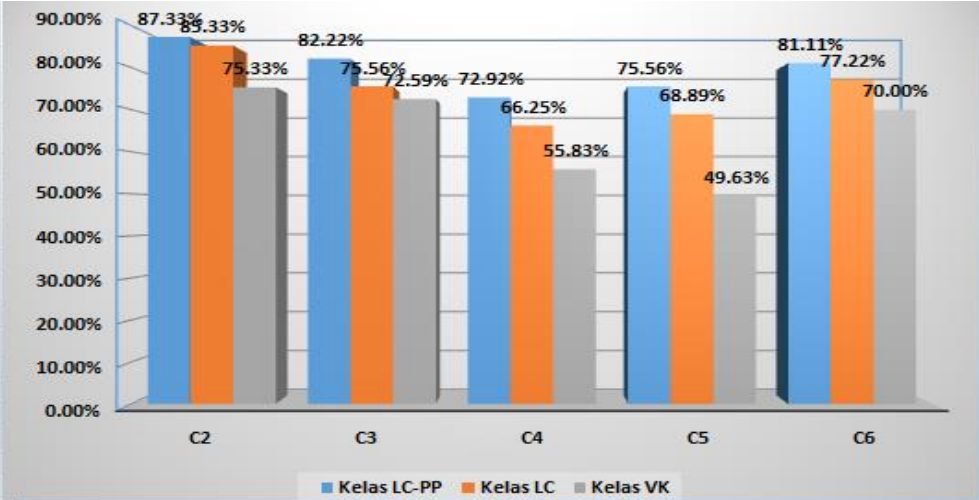

Gambar 2 Hasil Belajar Siswa ditinjau Tingkat Kognitif

Adapun jika ditinjau dari tingkat kognitif pada Gambar 2, menunjukkan bahwa siswa yang dibelajarkan dengan learning cycle 5E- problem posing dapat meningkatkan hasil belajar siswa baik tingkat kognitif $\mathrm{C} 2, \mathrm{C} 3, \mathrm{C} 4, \mathrm{C} 5$, maupun C6.

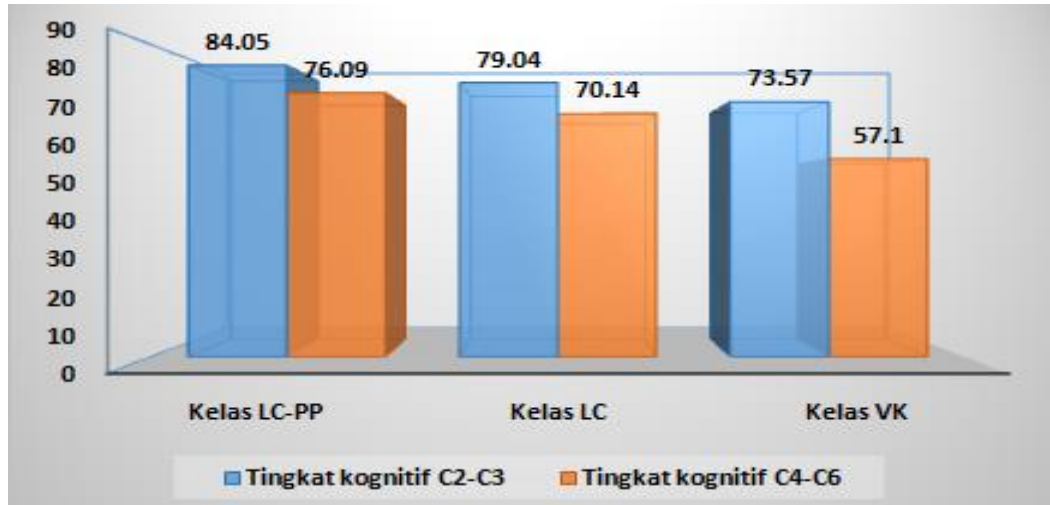

Gambar 3 Hasil Belajar Siswa ditinjau Tingkat Kognitif C4-C6 (HOTS)

Adapun rata-rata kemampuan berfikir tingkat tinggi (HOTS) siswa pada tes akhir terlihat pada Gambar 3 dapat diketahui bahwa siswa yang dibelajarkan model pembelajaran learning cycle $5 E$ - problem posing mendapat rata-rata hasil belajar tingkat tinggi $(79,06)$ yang lebih baik dari pada kelas model pembelajaran learning cycle $5 E$ 
$(70,14)$ dan kelas model verifikasi konvensional $(57,1)$. Selain itu, jika ditinjau dari setiap tingkat kognitif pada Gambar 4, menunjukkan bahwa siswa yang dibelajarkan learning cycle 5E-problem posing mendapat rata-rata hasil belajar tingkat kognitif $\mathrm{C} 4, \mathrm{C} 5$, dan C6 lebih baik dari pada kelas learning cycle $5 E$ dan kelas verifikasi konvensional

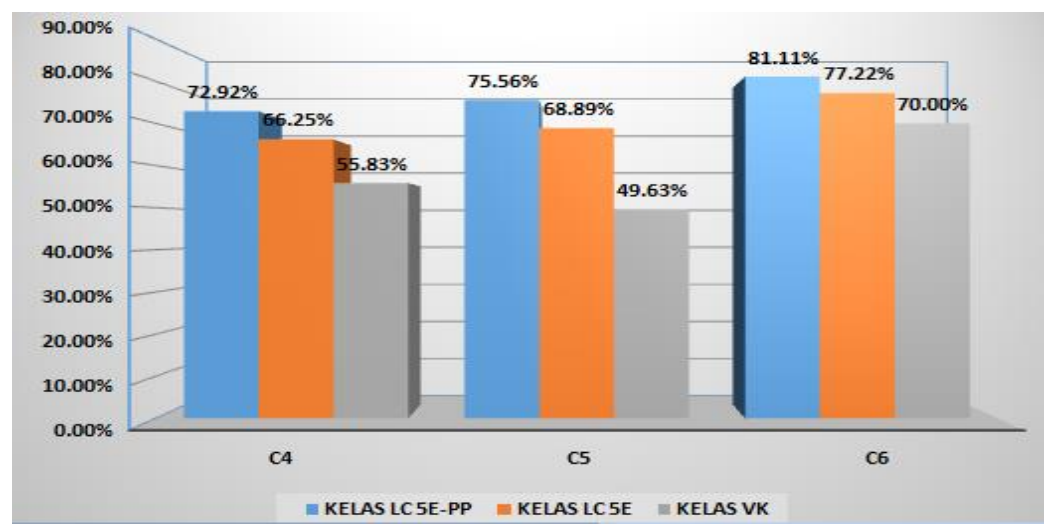

Gambar 4 Hasil Belajar Siswa ditinjau Setiap Tingkat Kognitif C4-C6 (HOTS)

Fenomena ini sesuai dengan Bybee (2006) dan Lawson (2001) bahwa learning cycle $5 E$ membantu siswa untuk penguasaan konsep. Penguasaan konsep materi kelarutan dan hasil kali kelarutan yang baik berkorelasi dengan hasil belajar akan meningkat. Learning cycle $5 E$ - problem posing membantu siswa terdorong mengeksplorasi sains secara mendalam dan membantu guru merencanakan pembelajaran konsep yang diajarkan secara mendalam pula (Duran, dkk.2011). Menurut Silver (1994) dan Silver, dkk. (1996) problem posing sangat penting untuk mengembangkan kemampuan algoritmik dan proses kognitif membuat masalah kembali dari berbagai situasi dan pengalaman. Problem posing juga memberikan kesempatan siswa untuk melakukan inkuiri dalam membuat soal sehingga menambah minat dan kepercayaan diri siswa (Chua dan Yeap, 2009).

\section{(b) Pengaruh kemampuan awal terhadap hasil belajar dan berfikir tingkat tinggi}

Pengaruh kemampuan awal siswa baik kemampuan awal siswa tinggi dan kemampuan awal siswa rendah terhadap hasil belajar dapat dilihat pada Gambar 5.

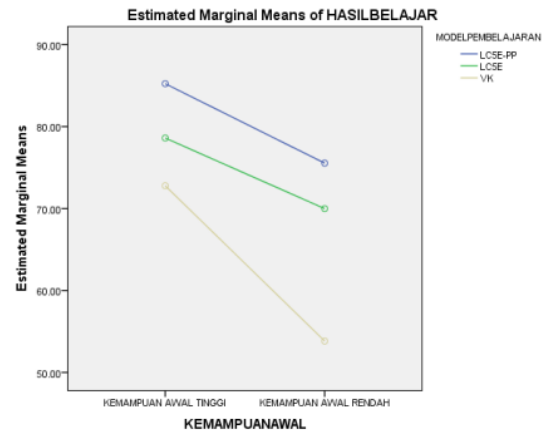

Gambar 5. Hasil belajar ditinjau dari Kemampuan Awal

Pada Gambar 5 dapat diketahui bahwa kelas learning cycle 5E-problem posing baik pada kemampuan awal siswa tinggi maupun kemampuan awal siswa memiliki ratarata hasil belajar lebih baik dari pada kelas learning cycle $5 E$ dengan verifikasi konvensional. Hal ini dikarenakan dalam learning cycle 5 E problem posing membantu siswa untuk mengeksplorasi sains secara mendalam dan membantu guru merencanakan 
pembelajaran konsep yang diajarkan secara mendalam pula (Duran, dkk.2011). Selain itu, kemampuan awal berkorelasi dengan hasil belajar siwa (Lipson. 1982). Hal ini didukung oleh Adam dan Bruce (1982) bahwa pemahaman siswa membutuhkan kemampuan awal untuk mempelajari pengetahuan baru dan fenomena yang terjadi akan sulit dipelajari bahkan tidak bermakna jika tidak ada kemampuan awal. Dalam learning cycle $5 E$ terdapat fase eggagemen, guru memaksimalkan mengeksplorasi kemampuan awal siswa untuk dikaitkan dengan materi yang dipelajari.

Selain itu, penilaian dapat ditinjau dari kemampuan awal siswa baik kemampuan awal siswa tinggi dan kemampuan awal siswa rendah terhadap kemampuan berfikir tingkat tinggi dapat dilihat pada Gambar 6.

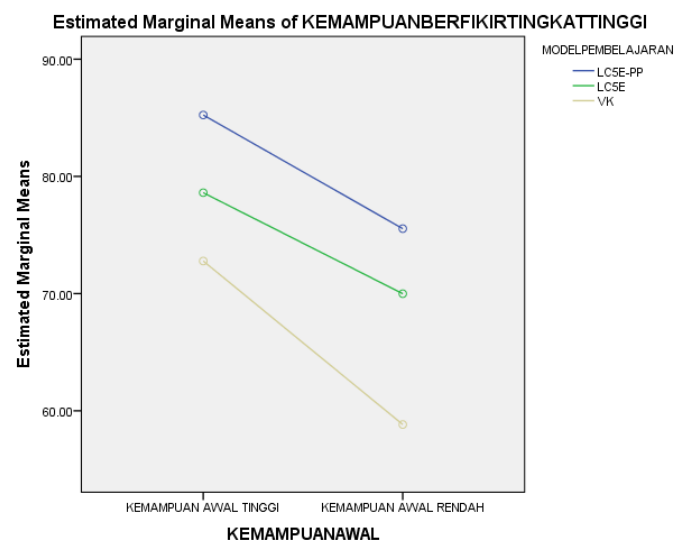

Gambar 6 Hasil Belajar Siswa Tingkat Kognitif C4-C6(HOTS) berdasarkan kemampuan awal siswa

Pada Gambar 6 dapat diketahui bahwa kelas learning cycle 5E-problem posing dengan kemampuan awal siswa tinggi dan kemampuan awal siswa rendah memiliki ratarata hasil belajar lebih baik dari pada kelas learning cycle $5 E$ dengan rata-rata hasil belajar dan kelas verifikasi konvensional.Hal ini dikarenakan learning cycle 5E-problem possing dapat meningkatkan kemampuan berfikir tingkat tinggi baik kemapuan konseptual dan algoritmik, didasarkan terpenuhi sintaks peningkatan berpikir kritis yang merupakan aspek kemampuan berfikir tingkat tinggi (Duron, 2006). Selain itu, adanya metode ilmiah dalam pembelajaran menguatkan berfkir tingkat tinggi (Schafersman, 1991)

(c) Uji pengaruh learning cycle $5 E$-problem posing terhadap hasil belajar dan kemampuan berfikir tingat tinggi siswa

Uji pengaruh learning cycle 5E- problem posing terhadap hasil belajar dan kemampuan berfikir tingat tinggi siswa, pada Tabel 2.

\begin{tabular}{lllll}
\hline \multicolumn{1}{c}{ Dependent Variable } & Df & F & Sig \\
\hline \multirow{2}{*}{$\begin{array}{l}\text { Kemampuan } \\
\text { Awal }\end{array}$} & Hasil belajar & 2 & 23,529 & 0,00 \\
\cline { 2 - 5 } & $\begin{array}{l}\text { Kemampuan Berfikir } \\
\text { Tingkat Tinggi }\end{array}$ & 2 & 19,371 & 0,00 \\
\hline $\begin{array}{l}\text { Model } \\
\text { pembelajaran }\end{array}$ & Hasil Belajar & 2 & 27,727 & 0,00 \\
\cline { 2 - 5 } & $\begin{array}{l}\text { Kemampuan Berfikir } \\
\text { Tingkat Tinggi }\end{array}$ & 2 & 18,496 & 0,00 \\
\hline
\end{tabular}




\begin{tabular}{lllll}
\hline Kemampuan & Hasil Belajar & 2 & 3,01 & 0,052 \\
\cline { 2 - 5 } $\begin{array}{l}\text { awal*Model } \\
\text { pembelajaran }\end{array}$ & $\begin{array}{l}\text { Kemampuan Berfikir } \\
\text { Tingkat Tinggi }\end{array}$ & 2 & 1,781 & 0,175 \\
\hline
\end{tabular}

Tabel 2 Uji Analisis Anakova Hasil Belajar Kelas Eksperimen Dan Kotrol

Pada Tabel 2 pengaruh model pembelajaran terhadap hasil belajar dan hasil belajar tingkat kognitif C4-C6 baik sebelum ditinjau dan sesudah ditinjau dari kemampuan awal siswa memilki $p$-value $0,00(<0,05)$ yang menunjukkan bahwa adanya perbedaan hasil belajar dan hasil belajar tingkat kognitif C4-C6 secara signifikan antara model pemeblajaran yang diterapkan. Hal ini menguatkan Gambar1-6. Selain itu, pada Tabel 2 ada tidaknya interaksi antara kemampuan awal siswa dengan model pembelajaran terhadap hasil belajar ( $p$-value $0,052(>0,05))$ dan kemampuan berfikir tingkat tinggi $(p$ value $0,175(>0,05)$ ) sehingga tidak ada interaksi kemampuan siswa dengan model pembelajaran terhadap hasil belajar siswa dan kemampuan berfikir tingkat tinggi. Oleh karena itu, model pembelajaran learning cycle 5E-problem posing dapat meningkatkan hasil belajar siswa dan kemampuan berfikir tingkat tinggi baik baik kepada siswa kemampuan tinggi maupun rendah

\section{KESIMPULAN}

Berdasarkan hasil penelitian dan pemaparan pembahasan, maka dapat disimpulkan bahwa keefektifan problem posing pada learning cycle $5 E$ dapat meningkatkan hasil belajar dan kemamapuan berfikir tingkat tinggi siswa ditinjau dari kemampuan awal siswa. Selain itu, tidak ada interaksi antara kemampuan awal dengan model pembelajaran, menjelaskan keefektifan problem posing pada learning cycle $5 E$ dalam meningkatkan kemampuan siswa baik siswa kemampuan tinggi maupun rendah.

\section{SARAN}

Beberapa saran yang dapat diberikan berdasarkan pada hasil penelitian untuk perbaikan penelitian lebih lanjut adalah: (1) kelemahan dalam penelitian ini lebih menitihberatkan pada konteks pengetahuan. Oleh karena itu, pengembangan penilaian lebih dikembangkan dalam variabel keterampilan proses dan dimensi sikap terhadap kimia. (2) keefektifan waktu dalam pelaksanaan model pembelajaran harus diperhatikan dalam mengoptimalkan keaktifan siswa, (3) perlunya motivasi kepada siswa oleh guru lebih diperhatikan dan ditingkatkan,mengingat pendekatan konstruktivisme menuntut siswa aktif dalam membangun pengetahuannya.

\section{DAFTAR RUJUKAN}

Abraham, M. R. \& Renner, J. W. 1986. The Sequence Of Learning Cycle Activities In High School Chemistry. Journal Of Research In Science Teaching. 23 (2): 121-143

Balitbang, 2013. Peta Indeks Kompetensi Sekolah SMA/MA berdasarkan Hasil Ujian Nasional 2013, (Online), (kemdikbud.go.id.), diakses tanggal 10 September 2015

Barke, H.D., Al Hazari \& Yitbarek, S.2009. Misconceptions in Chemistry. SpringerVerlag Berlin Heidelberg

Berkel, B.V., Pilot, A.,Bulte, A.M.W. 2009. Micro-Macro Thinking in Chemical Education: Why and How to Escape. Multiple Representations in Chemical Education. Springer Science Business Media B.V 
Bodner, G. M. 1986. Constructivism: A Theory Of Knowledge. Journal of Chemical Education, (Online), 63: 873-878, (chemed.chem.purdue.edu/chemed/.../pdf/24_Construct.pdf) diakses 1Januari 2017

Brown, S. L. \& Votaw, N. L. 2008. Liquid Motion Lamp: A Learning-Cycle Approach to Solubility, Science Activities: Classroom Projects and Curriculum Ideas, (Online), 45(1): 29-36, (http://dx.doi.org/10.3200/SATS.45.1.29-36)

Bybee, R. W., Taylor, J. A., Gardner, A., Scotter, P. V., Powell, J. C., Westbrook, A. \& Landes, N. 2006. The BSCS 5E Instructional Model: Origins, Effectiveness, and Applications (executive summary), (Online), (www. bscs.org ), diakses 5 Juni 2016

Chua, Puay H. \& Yeap, Ban H.2009. Problem posing performance of grade 9 students in singapore on an open-ended stimulus. (Online). (tsg.icme11.org/document/get/457), diakses 5 Juni 2016

Dasna, W. \& Fajaroh, F. 2007. Pembelajaran Dengan Model Siklus Belajar (Learning Cycle).(Online), (http//lubisgrafura.woodpress.com.pemeblajaran dengan model sirklus belajar learning cycle, diakses 5 November 2015

Davidowitz, B., Chittleborough, G. 2009. Linking the Macroscopic and Submicroscopic Levels: Diagrams .Multiple Representations in Chemical Education. Springer Science Business Media B.V

De Jong, O., Blonder, R., \& Oversby, J. 2013. How To Balance Chemistry Education Between Observing Phenomena And Thinking In Models, Balancing Between Phenomena And Models, (Online), (https://www.academia.edu), diakses 5 Juni 2017

Drive, R., Asoko, H., Leach, J., Mortimer, E.,\& Scott. 1994. Constructing Scientific Knowledge in the Classroom. 23 (7): 5-12

Duran, E., Duran, L., Haney, J. \& Scheuermann, A. 2011. Modifying the 5E instructional model to address the needs of all learners,(Online), (www.scilinks.org), diakses 5 Juni 2016

Duron, R., Limbach, B., Waugh W.2006. Critical Thinking Framework For Any Discipline, International Journal of Teaching and Learning in Higher Education, (Online), 17(2): 160-166, (www.sazlie.com/bahan/promotecriticalthinking.pdf), diakses 8 November 2014

Effendy. 1985. Pengaruh Pengajaran Ilmu Kimia dengan cara Inkuiri Tembimbing dan dengan cara Verifikasi terhadap pengembangan intelek dan Prestasi Belajar Mahasiswa IKIP Jurusan Pendidikan Kimia Tahun Pertama. Tesis tidak diterbitkan. Jakarta. Fakultas Pascasarjana IKIP Jakarta.

Effendy. 2002. Upaya untuk Mengurangi Kesalahan Konsep dalam Pengajaran Kimia dengan menggunakan Stategi Konflik Kognitif. Media komunikasi kimia, 2(6):1-22. Malang: JICA

English, L. D. 1997. Seventh-Grade Students Problem Posing From Open-Ended Situations, Online), (https://www.merga.net.au/.../Practical_English_1997.pdf). diakses 5 Juni 2016

Eren, C. 2008. Effects Of 5e Learning Cycle Model On Understanding Of State Of Matter And Solubility Concepts. Disertasi. Turki. Department of Secondary Science and Mathematics Education Middle, East Technical University 
Gilbert, John K and Treagust, David F. 2009. Introduction: Macro, Submicro and Symbolic Representations and the Relationship Between Them: Key Models in Chemical Education. Multiple Representations in Chemical Education. Springer Science Business Media B.V

Guzzetti B., T.E. Taylor, G.V. Glass, and W.S. Gammas. 1993. Promoting conceptual change in science: A comparative meta-analysis of instructional interventions from reading education and science education. Reading Research Quarterly, 28:117-159

Johnstone, Alex H.. 2000. Teaching of chemistry - logical or psychological?. Chemistry Education:Research And Practice In Europe, (Online), 1(1): 9-15, (www.elainegalvin.ie/wp-content/uploads/2014/.../teaching-of-chemistryJohnstone.pd...by AH JOHNSTONE - 2000), diakses 5Juni 2017

Karplus, Robert. 1977. Science Teaching And The Development Of Reasoning. Journal of Research in Science Teaching, 14( 2): 169-175

Kelly, Resa., Barrera, Juliet H.,\& Mohamed, Saheed C. 2010. An Analysis of Undergraduate General Chemistry Students' Misconceptions of the Submicroscopic Level of Precipitation Reactions. Journal of chemical education, (Online), 87, (https://www.researchgate.net/publication), diakses 5 Juni 2017

Kemendikbud. 2014. Konsep dan Implementasi Kurikulum 2013. Makalah Paparan Wakil Menteri Pendidikan dan Kebudayaan R.I Bidang Pendidikan , Jakarta, 14 Januari

King, FJ., Goodson L., Rohani F. 2011. Higher Order Thinking Skills. A publication of the Educational Services Program, now known as the Center for Advancement of Learning and Assessment, (Online), (www.cala.fsu.edu), diakses 5 Juni 2016

Krause, S. \& Tasooji, A. 2007. AC 2007-413: Diagnosing Students' Misconceptions On Solubility And Saturation For Understanding Of Phase Diagrams. American Society for Engineering Education, (Online), (https://www.researchgate.net/publication), diakses 5 Juni 2017

Lipson, Marjorie Youmans. 1982. Learning New Information From Text: The Role Of Prior Knowledge And Reading Ability. Journal of Reading Behavior, 14 (3)

Maier,Steven J. \& Marek Edmund A.2006. The Learning Cycle: A Reintroduction. Journal The Physics Teacher, 44

Munzenmaier, Cecelia. \& Rubin, Nancy. 2013. Perspectives Bloom's Taxonomy: What's Old Is New Again. The eLearning Guild. Scott Hanson

of Solubility Equilibrium. Journal of Chemical Education. (Online), 78(5), (https://www.researchgate.net/publication), diakses 5 Juni 2017

Piitalis, M., Christon, C., Mousoulides, N., Pitta-Pantazi, D. 2004. A Structural Model For Problem Posing. Proceedings of the 28th Conference of the International Group for the Psychology of Mathematics Education, (4): 49-56

Rahayu , Sri. 2012. Peningkatan Prestasi dan Proses Belajar Kimia Dasar Mahasiswa

Bilingual melalui Strategi Team-Based Learning. Malang: FMIPA Universitas

Negeri Malang

Rahayu, S. 2016. Meningkatkan Higher Order Thinking Skills(HOTS) Melalui Pembelajaran Literasi Sains. Disajikan dalam Seminar Nasional Pendidikan IPA, Pascasarjana UM, Malang, 8 Oktober 
Raviolo, A. 2001. Assessing Students' Conceptual Understanding. Journal of Chemical Education, (Online), 78 (5): 629-631, (JChemEd. Chem. Wisc. Edu), diakses 3 April 2016

Schafersman, Steven D. An Introduction to Critical Thinking, (Online), (http://www.freeinquiry.com/critical-thinking.html), diakses 5 Juni 2016

Silver, Edward A. 1994. On Mathematical Problem Posing. For the Learning of Mathematics, (Online), 14 (1) :19-28, (www.jstor.org/stable/40248099), diakses 5 Juni 2016

Silver, Edward A., \& Cai, Jinfa.1966. An Analysis of Arithmetic Problem Posing by Middle School Students. Journal for Research in Mathematics Education, 27(5): 521-539, (http://www.jstor.org/stable/749846), diakses 5 Juni 2016

Silver, Edward A., Downs, Joanna Mamona., Leung, Shukkwan S., \& Kenney, Patricia Ann. 1996. Posing Mathematical Problems: An Explorator. Journal for Research in Mathematics Education, 27(3): 293-309. (www.jstor.org/stable/749366 ), diakses 5 Juni 2016

Svinicki, Marilla. 1993-94. What they don't know can hurt them: The role of prior knowledge in learning. Essays on Teaching Excellence Toward the Best in the Academy, (Online), 5(4), (www.podnetwork.org), diakses 5 Juni 2016

Tan, Kim C.D., Goh, Ngoh K., Chia L.S. \& Treagust D.F. 2009. Linking the Macroscopic, Sub-microscopic and Symbolic Levels:The Case of Inorganic Qualitative Analysis . Multiple Representations in Chemical Education. Springer Science Business Media B.V

Thompson, Ross A. \& Zamboanga Byron L. 2004.. Academic Aptitude and Prior Knowledge as Predictors of Student Achievement in Introduction to Psychology. Journal of Educational Psychology, 96 (4): 778-784

Wu, Hsin-Kai, Krajcik \& Joseph S., Soloway , Elliot .2001. Promoting Understanding of Chemical Representations: Students' Use of a Visualization Tool in the Classroom. Journal of Research in Science Teaching, (Online), 38(7): 821-842, (https://pdfs.semanticscholar.org), diakses 13 January 2015 